\title{
Internal hive temperature as a means of monitoring honey bee colony health in a migratory beekeeping operation before and during winter
}

\author{
William G. Meikle, Milagra Weiss, Patrick W. Maes, William Fitz, Lucy A. Snyder, \\ Tim Sheehan, Brendon M. Mott, Kirk E. Anderson
}

Carl Hayden Bee Research Center, 2000 E. Allen Rd, Tucson, AZ 85719, USA

Received 4 November 2016 - Revised 27 March 2017 - Accepted 20 April 2017

\begin{abstract}
Internal temperatures of honey bee hives kept at different sites in North Dakota were monitored before and during winter to evaluate the effects of treatment, in the form of exposure to commercial pollination, and location on colony health. In October, hives exposed to commercial pollination during the summer had fewer adult bees and less brood than hives kept near natural forage, as well as lower average temperatures throughout winter. Within-day temperature variability was higher among hives exposed to commercial agriculture than for those kept near natural forage, indicating reduced temperature control. Fungicides, insecticides, varroacides, and an herbicide were detected in bee bread and wax samples; no major differences were observed either in the diversity or in the concentrations of agrochemicals with the exception of chlorpyrifos at one site. Varroa and Nosema densities were low overall. Data from the same site used in successive years showed significantly more brood the first year, as well as lower temperature variability; high levels of chlorpyrifos were detected in bee bread of colonies in the second year. Colony average temperature and temperature variability were informative with respect to colony phenology and post-winter status.
\end{abstract}

Hive temperature / adult bee weight / brood production / pesticide residues / Nosema / temperature amplitudes / bee colony phenology

\section{INTRODUCTION}

Variation in landscape exposure in summer and fall can influence the health of honey bee colonies via many mechanisms including effects from pesticide contamination, disease, or malnutrition (Simone-Finstrom et al. 2016). Of particular concern has been overwintering loss across space and time (Chauzat et al. 2010; Genersch et al. 2010; Lee et al. 2015; Runckel et al. 2011). Overwintering loss

Electronic supplementary material The online version of this article (doi:10.1007/s13592-017-0512-8) contains supplementary material, which is available to authorized users.

Corresponding author: W. Meikle, william.meikle@ars.usda.gov

Manuscript Editor: Stan Schneider rate is an important measure because a healthy colony is worth a premium in commercial pollination; it may be split into two or more colonies to increase holdings; and it is more likely to produce large amounts of honey the following year (Harris 2009). Conversely, many diseases and deficiencies can manifest or amplify during the overwintering period including Varroa, various viruses, trypanosomes, Nosema disease, and non-Nosema dysentery (Runckel et al. 2011; Dainat et al. 2012; Pickard and El-Shemy, 1989; Schwarz et al. 2015; Van Dooremalen et al. 2012). Pesticide exposure in the fall can compromise immune defenses, increase Nosema and Varroa levels, and decrease colony growth during and after overwintering (Pettis et al. 2013; Dively et al. 2015; Meikle et al. 2016a).

Honey bee colony survival during winter depends on worker bee health and on the quantity 
and quality of stored food, while the principle interaction with the environment is in temperature management. Homeostasis and colony changes during winter have been studied using calorimeters and in-hive temperature arrays (Kronenberg and Heller 1982; Meikle and Holst 2015; Schmolz et al. 1995). Survivorship and development of brood, particularly pre-pupae and pupae, depends on a continuous temperature of about $34-36{ }^{\circ} \mathrm{C}$ (Jones et al. 2004; Stabentheiner et al. 2010; Wang et al. 2016). Bee colonies also influence temperature in the absence of brood (Gates 1914). The ability of a bee colony to maintain temperature homeostasis in at least part of the hive is the result of coordinated behavior and thus may be indicative of colony function and health. Thus, monitoring that temperature may reveal aspects of colony health, even if the underlying reasons or mechanisms for differences in temperature control among colonies are not fully understood. Here, we used continuous temperature data as a response variable to distinguish group-level effects of different migratory routes on honey bee colony health and survivorship.

\section{MATERIALS AND METHODS}

2014-2015 trial In mid-March 2014, 160 migratory bee colonies were built from large, healthy parent colonies sourced from Browning's Honey Co., Inc. (Idaho Falls, ID) which, under agreement, also transported and managed all colonies in this study. These studies were conducted on private land, with permission obtained by Browning's Honey Co., Inc. Each new colony received a queen cell reared from the same Carniolan bee breeder. Langstroth hives, consisting of two deep boxes (43.7 1 capacity) with nine frames in the lower box, were fitted with migratory-style (flat) lids, 3-10-year-old wax comb, and in-hive syrup feeders and installed on four-way pallets. On April 20, all colonies were moved from the orchards to non-agricultural sites in California and fed $12 \mathrm{~L}$ of syrup each. On May 5, the hives were moved to North Dakota and divided equally into two sites surrounded by primarily non-agricultural forage: the Legge site $\left(46^{\circ} 59^{\prime} 44^{\prime \prime} \mathrm{N}, 98^{\circ} 10^{\prime} 18^{\prime \prime}\right.$ $\mathrm{W})$, and the Frolich site $\left(47^{\circ} 00^{\prime} 44^{\prime \prime} \mathrm{N}, 98^{\circ} 05^{\prime}\right.$ $\left.16^{\prime \prime} \mathrm{W}\right)$. Areas surrounding those sites were $<50 \%$ under agriculture (www.nass.usda.gov) (see
Online Resource 1). Legge was within foraging distance $(<2 \mathrm{~km})$ of the designated Conservation Reserve Program (CRP) land in 2014. On May 19 , hives were visually assessed and frame strength (number of frame sides covered by adult bees-see Smart et al. [2016]) was uniformly between five and seven frames. Hives were then divided into two main groups: those exposed to agricultural pollination and those not (or much less) exposed. Eighty hives at Legge and Frolich, designated the Legge and Frolich1 apiaries, respectively, remained there until October. On July 2 , 40 hives from Legge and 40 hives from Frolich were moved for canola seed pollination, as a paid service, to yard N5924 ( $47^{\circ} 52^{\prime} 03^{\prime \prime}$ N, $97^{\circ} 31^{\prime} 58$ " W). During canola bloom, a foliar fungicide, Proline ${ }^{\circledR}$ (prothioconazole), was applied (Z. Browning, pers. comm.). On July 25, 40 hives from the canola yard were moved to the "Moch" ( $\left.46^{\circ} 39^{\prime} 47^{\prime \prime} \mathrm{N},-100^{\circ} 09^{\prime} 26^{\prime \prime} \mathrm{W}\right)$ yard, designated the AG1 apiary, and 40 to the "Scheer" ( $46^{\circ} 34^{\prime}$ $\left.34^{\prime \prime} \mathrm{N},-100^{\circ} 18^{\prime} 01^{\prime \prime} \mathrm{W}\right)$ yard, designated the AG2 apiary. The Moch and Scheer apiaries were designated the "Agriculture" group, and the Frolich and Legge apiaries were designated the "CRP" group. Moch and Scheer yards were about $1 \mathrm{~km}$ from blooming alfalfa and clover, as well as sunflowers subjected to aerial application of biocides, including evening treatments of chlorpyrifos (Z. Browning, pers. comm.). Honey was harvested in late summer, and all 160 hives shipped to Idaho on October 8 (hives were never placed in proximity to hives from outside the study). On November 22, hives were installed in a temperature-controlled warehouse near Firth, Idaho, with constant conditions of about $25 \%$ r.h. and $7^{\circ} \mathrm{C}$. On January 20 , hives were shipped by truck to almond orchards near Snelling, California, and evaluated a week later (Table I).

2015-2016 trial In April 2015, 80 hives were constructed and managed in a similar fashion as for the 2014-2015 trial. All hives were sent to the Frolich site until mid-July, after which one group was sent to Thilmony Farm (46 $52^{\prime} 36^{\prime \prime} \mathrm{N}, 97^{\circ}$ $54^{\prime} 08^{\prime \prime} \mathrm{W}$ ) and another group to Thilmony West (46 52' 38.02" N, 97 57' 33.38" W), about $4.5 \mathrm{~km}$ due west. The remaining hives were kept at the Frolich site. All hives remained at those sites 
Table I. Migratory routes of the treatment groups in 2014-15

\begin{tabular}{|c|c|c|c|c|c|c|c|}
\hline \multirow[t]{2}{*}{ Apiary } & \multicolumn{5}{|l|}{2014} & \multicolumn{2}{|l|}{2015} \\
\hline & $\begin{array}{l}\text { Apr. } 20- \\
\text { May } 4\end{array}$ & $\begin{array}{l}\text { May5- } \\
\text { July } 1\end{array}$ & July 2-24 & $\begin{array}{l}\text { July } 25- \\
\text { Oct. } 7\end{array}$ & Oct. 8-Nov. 20 & $\begin{array}{l}\text { Nov. } 22- \\
\text { Jan. } 20\end{array}$ & Jan. 21-27 \\
\hline AG1 & N.E. CA & $\begin{array}{l}\text { Legge/ } \\
\text { Frolich ND }\end{array}$ & $\begin{array}{l}\text { N5924 ND } \\
\text { (canola) }\end{array}$ & $\begin{array}{l}\text { Moch ND } \\
\text { (sunflowers) }\end{array}$ & Holding yard ID & Storage ID & Snelling CA \\
\hline AG2 & N.E. CA & $\begin{array}{l}\text { Legge/ } \\
\text { Frolich ND }\end{array}$ & $\begin{array}{l}\text { N5924 ND } \\
\text { (canola) }\end{array}$ & $\begin{array}{l}\text { Scheer ND } \\
\quad \text { (sunflowers) }\end{array}$ & Holding yard ID & Storage ID & Snelling CA \\
\hline Legge & N.E. CA & Legge ND & Legge ND & Legge ND & Holding yard ID & Storage ID & Snelling CA \\
\hline Frolich1 & N.E. CA & Frolich ND & Frolich ND & Frolich ND & Holding yard ID & Storage ID & Snelling CA \\
\hline
\end{tabular}

"Legge," "Frolich," "Moch," and "Scheer" refer to apiary yards (see text for details). CA, ND, and ID refer to the respective states in the USA. The AG1 and AG2 apiaries were placed in the "Agriculture" group and the Legge and Frolich1 apiaries were placed in the "CRP" group

until they were moved on November 15 to the same warehouse in Idaho as the previous year (Table II). While no hives at any of the sites were used commercially for canola or sunflower pollination, fields of both crops were within foraging distance of all hives. Colonies were not differentially exposed to agriculture as in the previous year; instead, location effects were explored within the year, and colony data from the Frolich apiary were compared across years.

Hives in both trials received $11-15 \mathrm{~L}$ of a solution of $78 \%$ simple sugars $(50 / 50 \mathrm{w} / \mathrm{w}$ mixture of sucrose and high-fructose corn syrup), hereafter "syrup," and approximately $1 \mathrm{~kg}$ of a commercial protein supplement three times: (1) before move to North Dakota; (2) before spring bloom (May 1 to June 10); and (3) after fall bloom (early September). In the spring and fall, all hives were treated with patties composed of granulated sugar, shortening, thymol, menthol, lemongrass oil, eucalyptus oil, sweet orange oil, and camphor oil.
Apivar® was applied on May 10, and supers and queen excluders were installed for honey production on June 15. Hives were treated with Fumagilin-B, tylosin, and Terramycin mixed in powdered sugar, and Apivar® after honey harvest in September.

\subsection{Discrete colony measures}

From October 11 to $15,2014,11-12$ hives per apiary were randomly selected (total of 47 hives) to determine total adult bee mass, average frame weight, and capped brood surface area (see Meikle et al. 2016b). For each hive, all hive parts (lid, boxes, bottom board, feeder, etc.) were weighed on a portable electronic scale. Individual frames were gently shaken to dislodge adult bees, weighed, photographed on both sides using a 16.3 megapixel digital camera (Pentax K-01, Ricoh Imaging Co., Ltd.), and replaced in the hive. The square centimeter of the sealed brood was

Table II. Migratory routes of the treatment groups in 2015-16

\begin{tabular}{lllllll}
\hline Treatment group & 2015 & & & 2016 & \\
\cline { 2 - 3 } \cline { 6 - 7 } & Apr. 15-29 & Apr. 30-July 15 & July 15-Nov. 16 & & Nov. 18-Jan. 31 & Feb. 1-6 \\
\hline WestThil & Eastern CA & Frolich ND & Thilmony West ND & & Storage ID & Firebaugh CA \\
EastThil & Eastern CA & Frolich ND & Thilmony Farms ND & & Storage ID & Firebaugh CA \\
Frolich2 & Eastern CA & Frolich ND & Frolich ND & & Storage ID & Firebaugh CA \\
\hline
\end{tabular}

"Frolich," "Thilmony Farms," and "Thilmony West" refer to apiary yards (see text for details). CA, ND, and ID refer to the respective states in the USA 
estimated from frame photographs using ImageJ version 1.47 software (W. Rasband, National Institutes of Health, USA). Frame values per hive were summed to provide the total brood surface area. Total adult bee mass was determined by summing weights of all hive parts including frames, and subtracting that value from the total hive weight obtained the next morning before bees were flying. At the end of January 2015, those hives were evaluated again. All hives were assessed for frame strength post winter by staff from Browning's Honey Co. in the almond orchard. The same procedures were followed the following year except frame strength assessment.

\subsection{Continuous temperature and humidity monitoring}

After evaluation of each hive in October, 2014, temperature sensors (iButton Thermochron, Maxim Integrated, San Jose, CA, USA) were placed in small wire mesh bags and attached to the center of the top rail of the fifth frame in the lower box and combined temperature and r.h. sensors (Hygrochron) were attached to the center of the bottom rail of the same frame. Thermochron sensors recorded temperature hourly and Hygrochron sensors every $2 \mathrm{~h}$ (to ensure sufficient memory). Relative humidity data were converted to absolute humidity ( $g$ water per $\mathrm{m}^{3}$ ). For the second experiment, in July 2015 a single Thermochron was installed in each hive in the top center of the bottom box, as in the first experiment; those sensors were replaced in October and subsequently recovered in February 2016.

Temperature data were divided into two components: the running average, calculated by averaging temperatures over $12 \mathrm{~h}$ before and after a given hour (for a total of $25 \mathrm{~h}$ ), and (2) the daily detrended temperature, calculated as the difference between the raw data and the running average temperature (see Meikle et al. 2016b). The running average shows the longer-term $(\geq 25-h)$ trends, while the detrended data shows the within-day $(<25-h)$ changes. Sine curves were fit 3-day subsamples of detrended data taken sequentially by day and curve amplitudes, representing estimates of daily temperature variability, were used as a response variable. Amplitude datasets were reduced to a data point every 5 days to ensure no overlap between 3-day samples. For consistency, running average data were reduced in the same fashion.

\subsection{Detection of Varroa, Nosema, and pesticide residues}

At each hive evaluation, several hundred bees were brushed from a frame on the edge of the brood nest into $50-\mathrm{mL}$ centrifuge tubes and placed on dry ice in the field. The edge of the brood nest was sampled to reduce the chance of collecting the queen and to avoid high proportions of either very young bees or older foragers (Lee et al. 2010). The samples were later transferred to a freezer at $-80{ }^{\circ} \mathrm{C}$. A sample of $200-300$ bees was placed in $50 \mathrm{~mL}$ of $70 \%$ ethanol and agitated for several minutes, and all Varroa and bees were counted. To estimate Nosema spore load for each hive sample, five subsamples of five bees were ground with $2.5 \mathrm{~mL}$ distilled water, $5-1010-\mu \mathrm{L}$ aliquots placed on a hemocytometer, and spores counted at $400 \times$. Nosema ceranae and N. apis were distinguished visually (Fries et al. 2013). For the 20142015 experiment, pollen samples were collected from four selected hives in each group. Samples were combined to form three samples of $3 \mathrm{~g}$ each per sampling occasion and were subjected to a full panel (174 compounds) test of pesticide residues by the National Science Laboratories, USDAAMS, Gastonia, North Carolina. Wax samples were collected from the same hives but submitted as single samples per treatment group. For the 2015-2016 experiment, pollen samples were collected in October; samples from all hives were combined to form a single composite sample for each treatment group.

\subsection{Statistical analyses}

Total adult bee weight and brood surface area were regressed on temperature parameters (PROC REG). Treatment effects were evaluated using mixed-model ANOVA (PROC GLIMMIX, SAS Inc. 2012) with post hoc contrasts of least squares mean differences as required. Dependent variables were evaluated for normality using fit statistics and probability plots; variables with large deviations 
from normality were re-evaluated after log or square root transformation. Degrees of freedom were calculated using the Satterthwaite method, and residual plots assessed for variance homogeneity. Temperature amplitudes were reduced to a data point every 5 days for repeated measures MANOVA to ensure no overlap of subsamples, and post hoc contrasts were conducted using the Bonferroni adjustment. For consistency, running average data were similarly reduced. The covariance structure with the lowest Akaike information criterion was chosen among unstructured, compound symmetric, autoregressive, autoregressive moving average, and ante-dependence models. Residuals were included in the RANDOM statement and denominator d.f. calculated using the Kenward-Roger method. All temperature data are provided (see Online Resource 2).

\section{RESULTS}

\subsection{Discrete colony measures}

In 2014-2015, honey bee colonies in the CRP group were significantly higher prior to overwintering with respect to total adult bee mass $\left(F_{1,43}=14.01, P=0.0005\right)$ and amount of capped brood $\left(F_{1,38}=4.16, P=0.0483\right)$ but not average frame weight $(P=0.08)$ (Table III). Changes in total adult bee mass during winter were not different between groups $(P=0.70)$, indicating that while some colonies may have suffered higher losses than others, this could be explained by their population size prior to winter and not to a differential treatment effect during winter (Table IV).
Average frame weight losses during winter were significantly greater for the CRP colonies after controlling for total adult bee mass the previous fall $\left(F_{1,40}=10.04, P=0.0029\right)$. By late January, brood production was significantly higher in the CRP colonies than in the Agricultural colonies (non-parametric one-way ANOVA, $\left.F_{1,38}=10.51, P=0.0025\right)$ : nine out of 12 hives in the group had brood, but only four of 11 in the Frolich1 group, one of 11 in the AG2 group, and none of 10 in the AG1 group did. From a commercial point of view, far more hives reached six or more frames of adult bees in the Legge and Frolich1 groups than in the other groups (Table V).

In 2015-2016, treatment groups were significantly different prior to overwintering with respect to total adult bee mass $\left(F_{2,56}=6.43\right.$, $P=0.0031)$ and capped brood surface area $\left(F_{2,57}=4.07, P=0.0223\right)$ but not with respect to average frame weight $(P=0.24)$. Treatment groups were significantly different with respect to both change in total adult bee weight during winter $\left(F_{2,48}=12.17, P<0.0001\right)$ and frame weight loss $\left(F_{2,52}=14.61, P<0.0001\right)$ after controlling for adult bee mass in the fall. WestThil and EastThil groups had the largest adult bee masses during the fall, but they also experienced the largest decreases in mass, and decreases in frame weights, during winter storage.

\subsection{Temperature and colony phenology}

Temperature data for the 2014-2015 experiment were divided into three parts: (1) prior to storage in the warehouse (Oct. 16-Nov. 20), or

Table III. Average total adult bee weight, frame weight, and capped brood surface area prior to overwintering for hives in different migratory trajectories

\begin{tabular}{llcccccrl}
\hline Year & Group & No. of hives & Adult bee mass $(\mathrm{g}) \pm \mathrm{SE}$ & \multicolumn{2}{l}{$\begin{array}{l}\text { Frame weight } \\
(\mathrm{g}) \pm \mathrm{SE}\end{array}$} & \multicolumn{3}{c}{$\begin{array}{l}\text { Capped brood } \\
\left(\mathrm{cm}^{2}\right) \pm \mathrm{SE}\end{array}$} \\
\hline $2014-2015$ & Agric. & 23 & $1349 \pm 113$ & $\mathrm{a}$ & $1880 \pm 45$ & $\mathrm{a}$ & $339 \pm 44$ & $\mathrm{a}$ \\
& CRP & 24 & $2379 \pm 200$ & $\mathrm{~b}$ & $2036 \pm 74$ & $\mathrm{a}$ & $514 \pm 52$ & $\mathrm{~b}$ \\
$2015-2016$ & WestThil & 16 & $3444 \pm 191$ & $\mathrm{a}$ & $1804 \pm 57$ & $\mathrm{a}$ & $87 \pm 36$ & $\mathrm{ab}$ \\
& EastThil & 16 & $3090 \pm 231$ & $\mathrm{ab}$ & $1666 \pm 59$ & $\mathrm{a}$ & $144 \pm 44$ & $\mathrm{a}$ \\
& Frolich2 & 27 & $2543 \pm 152$ & $\mathrm{~b}$ & $1724 \pm 45$ & $\mathrm{a}$ & $57 \pm 21$ & $\mathrm{~b}$ \\
\hline
\end{tabular}

Values within a column and within year and which have no letters in common are significantly different at $\alpha=0.05$ 
Table IV. Average changes in total adult bee weight and frame weight (after controlling for total adult bee weight) during overwintering, and surface area of capped brood immediately after overwintering, for hives in different migratory trajectories

\begin{tabular}{|c|c|c|c|c|c|c|c|c|}
\hline \multirow{2}{*}{$\begin{array}{l}\text { Year } \\
2014-2015\end{array}$} & \multirow{2}{*}{$\begin{array}{l}\text { Group } \\
\text { Agric. }\end{array}$} & \multirow{2}{*}{$\begin{array}{c}\text { No. of hives } \\
23\end{array}$} & \multicolumn{2}{|c|}{$\begin{array}{l}\text { Adult bee mass } \\
\text { change }(\mathrm{g}) \pm \mathrm{SE}\end{array}$} & \multicolumn{2}{|c|}{$\begin{array}{l}\text { Frame weight } \\
\text { change }(\mathrm{g}) \pm \mathrm{SE}\end{array}$} & \multicolumn{2}{|c|}{$\begin{array}{l}\text { Capped brood } \\
\left(\mathrm{cm}^{2}\right) \pm \mathrm{SE}\end{array}$} \\
\hline & & & $427 \pm 86$ & $\mathrm{a}$ & $282 \pm 18$ & $\mathrm{a}$ & $2 \pm 2$ & a \\
\hline & CRP & 24 & $637 \pm 131$ & $\mathrm{a}$ & $374 \pm 22$ & $\mathrm{~b}$ & $77 \pm 23$ & $\mathrm{~b}$ \\
\hline \multirow[t]{3}{*}{$2015-2016$} & WestThil & 16 & $2211 \pm 259$ & $\mathrm{a}$ & $273 \pm 20$ & $\mathrm{a}$ & $61 \pm 14$ & $\mathrm{a}$ \\
\hline & EastThil & 16 & $1612 \pm 214$ & $\mathrm{a}$ & $456 \pm 105$ & $\mathrm{a}$ & $55 \pm 18$ & $\mathrm{a}$ \\
\hline & Frolich2 & 27 & $1021 \pm 122$ & $\mathrm{~b}$ & $135 \pm 20$ & $\mathrm{~b}$ & $48 \pm 12$ & $\mathrm{a}$ \\
\hline
\end{tabular}

Values within a column and within year and which have no letters in common are significantly different at $\alpha=0.05$

"fall"; (2) the time in the warehouse (Nov. 21Jan. 19) or "winter"; and (3) after removal from the warehouse (Jan. 20-27), or "post-winter." Ambient and within-hive temperatures decreased in general during the fall, and they were stable in the warehouse until removal of the hives in January (Figure 1). Two colonies in the Frolich1 group and one each in the AG1 and AG2 groups died after inspection in October; their temperature profiles were easy to distinguish from those of surviving colonies (see Online Resource 3 Figure S1) and excluded from analyses. Initially, average within-hive temperatures were similar among hives, but as ambient temperatures dropped, differences between the groups appeared. Detrended temperature amplitudes were comparatively high in the fall, when hives were exposed to daily ambient temperature fluctuations, then decreased to low levels during winter in the controlledtemperature warehouse, and finally increased to their highest levels post winter.
Absolute humidity in the 2014-2015 experiment was positively correlated with (1) temperature at the same position post winter $\left(F_{1,25}=267.63 ; P<0.0001 ; r^{2}=0.9112\right) ;(2)$ temperature at the upper position in the lower box at that time $\left(F_{1,25}=46.49 ; P<0.0001\right.$; $\left.r^{2}=0.6363\right)$; and (3) log adult brood weight at final evaluation $\left(F_{1,25}=62.14 ; P<0.0001\right.$; $\left.r^{2}=0.7016\right)$. Like temperature, treatment had a significant effect on absolute humidity when total adult bee weight was held as a covariate $\left(F_{3,21}=6.15, P=0.0036\right)$ (Figure 2). Honey bees have been found to regulate humidity in the nest (Human et al. 2006), but in this study humidity did not provide additional information.

Temperature data in the 2015-2016 study were divided into four parts: (1) summer (July 29Aug. 31); (2) fall (Sept. 1-Nov. 15); (3) winter (Nov. 20-Jan. 24); and (4) post winter (Jan. 31Feb. 4). Both ambient and within-hive temperatures decreased in general in the fall, and were

Table V. Grades for almond pollination of adult bees of apiaries with four different landscape histories

\begin{tabular}{|c|c|c|c|c|c|c|c|}
\hline \multirow[t]{2}{*}{ Treatment } & \multirow[t]{2}{*}{ Apiary } & \multirow[t]{2}{*}{ Primary honey source } & \multirow[t]{2}{*}{ No. of hives } & \multicolumn{4}{|c|}{$\begin{array}{l}\text { Almond grade: percent of colonies categorized by } \\
\text { frame counts of adult bees }{ }^{\text {a }}\end{array}$} \\
\hline & & & & $\geq 6$ & $5-3$ & $2-1$ & Dead \\
\hline \multirow[t]{2}{*}{ Agriculture } & AG1 & Canola and sunflowers & 36 & $6.7 \%$ & $22.2 \%$ & $47.2 \%$ & $19.4 \%$ \\
\hline & AG2 & Canola and sunflowers & 40 & $32.5 \%$ & $22.5 \%$ & $25.0 \%$ & $20.0 \%$ \\
\hline \multirow[t]{2}{*}{ CRP } & Legge & Clover & 40 & $95.0 \%$ & $5.0 \%$ & $0.0 \%$ & $0.0 \%$ \\
\hline & Frolich1 & Clover and alfalfa & 40 & $60.0 \%$ & $17.5 \%$ & $12.5 \%$ & $10.0 \%$ \\
\hline
\end{tabular}

\footnotetext{
a Proportion of colonies that were "Grade A" orchard bees ( $\geq 6$ frames [49]) just prior to almond pollination differs significantly among all four groups $(P \leq 0.001)$
} 

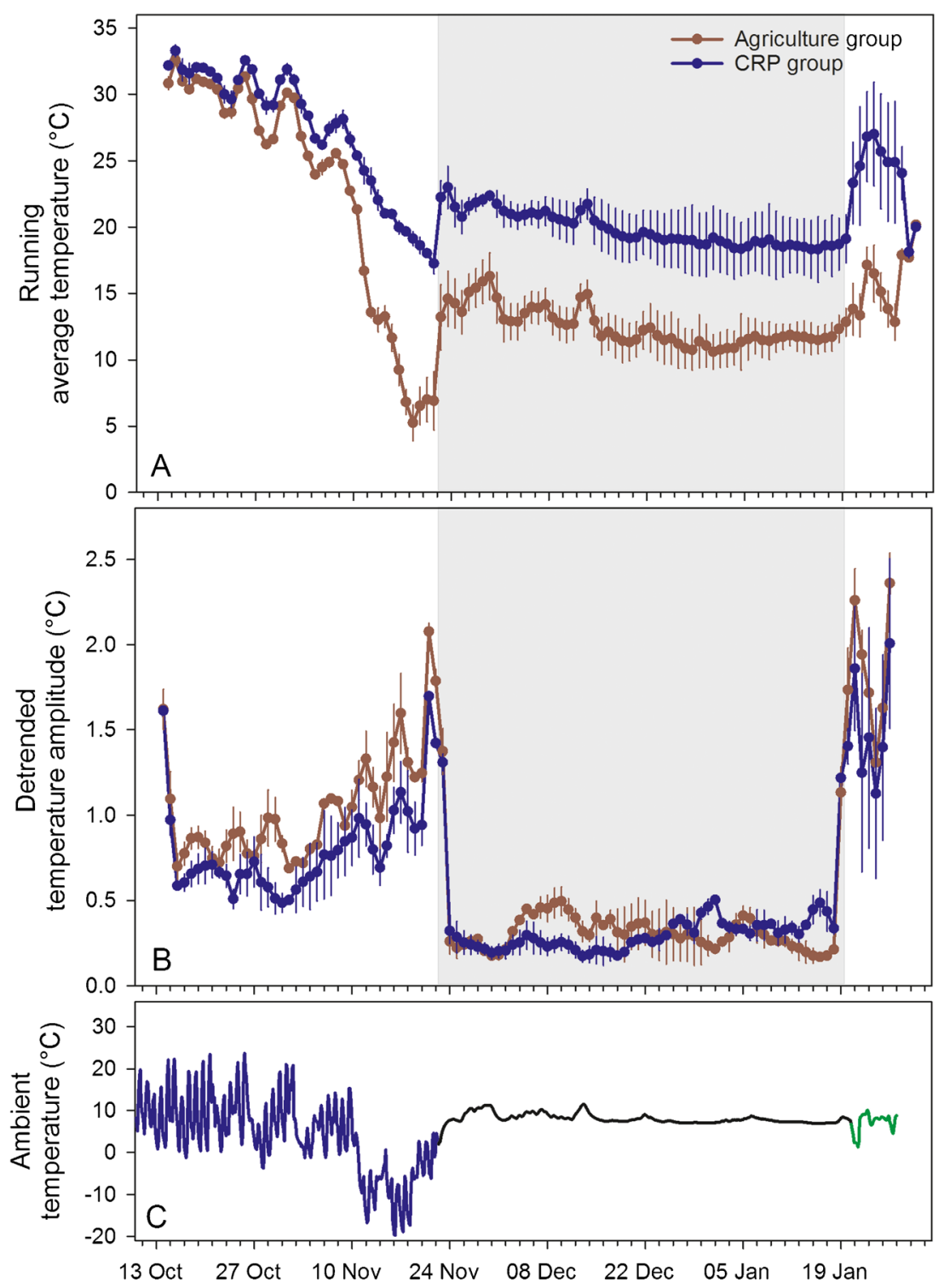

Figure 1. Average daily within-hive temperatures (a) and average daily detrended within-hive temperature amplitudes (b) for hives in two treatment groups kept outside in Idaho Falls, ID, in October 2014, then installed in a warehouse near Firth, ID, during winter 2014 (indicated by the gray zone), and finally shipped to Snelling, CA, in January 2015; ambient temperatures during the study period (c), with blue line showing ambient temperatures in Idaho Falls, ID (www.wunderground.com), black line showing ambient temperatures inside the warehouse in Idaho, and green line showing ambient temperatures during and after shipment to CA.

stable in the warehouse until removal of the hives (Figure 3). Two hives, both in the EastThil group, died after evaluation in October, and their data were excluded from further analyses. Detrended temperature amplitudes followed the same general pattern as the previous year.

\subsubsection{Adult bee mass and average temperature}

Within-hive temperature, averaged over the first 7 days after installation of the sensors, was not significantly correlated with log-transformed adult bee mass measured in fall 2014 (Oct. 16-22, 2014) 


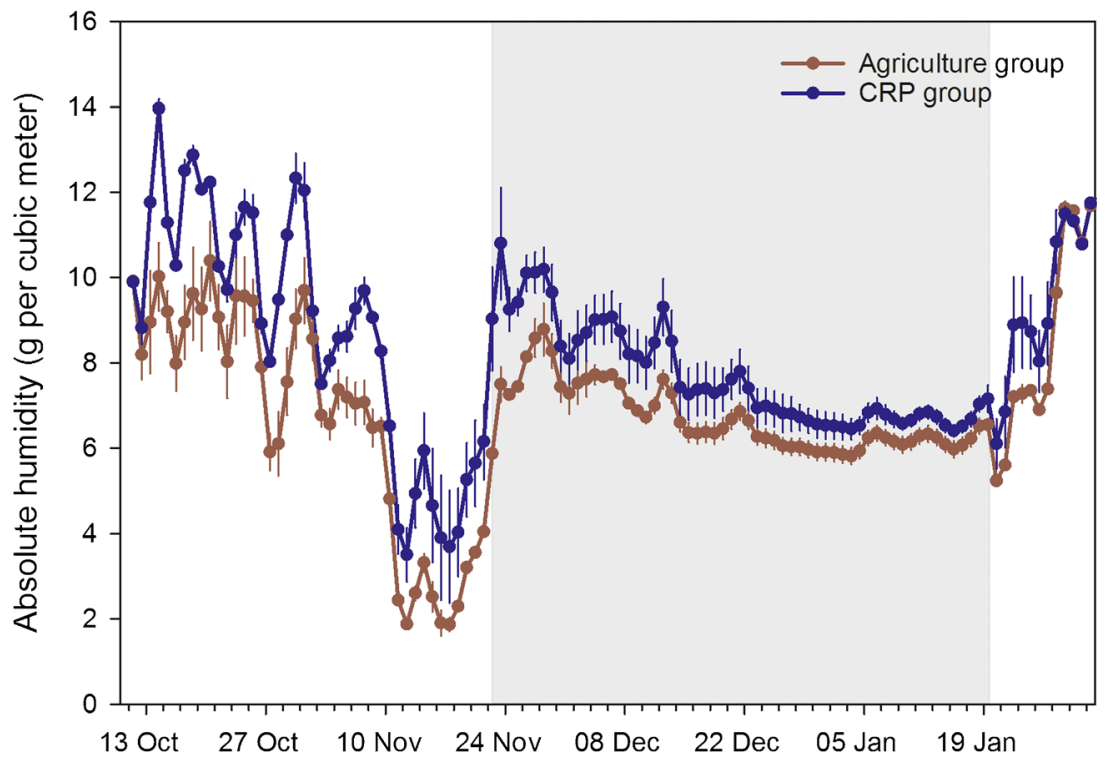

Figure 2. Average within-hive absolute humidity for 27 bee colonies in two treatment groups kept outside in Idaho Falls, ID, in October 2014, then installed in a warehouse near Firth, ID, during winter 2014 (indicated by the gray zone ); and finally shipped to Snelling, CA, in January 2015. Colonies had been subjected to one of four migratory routes prior to overwintering (see text for details).

$(P=0.32$ for the Agriculture group and 0.57 for the CRP group). Within-hive temperature averaged over the winter period (Nov. 22, 2014-Jan. 15, 2015) was correlated with log adult bee mass measured post winter for hives in the CRP group $\left(F_{1,19}=17.53\right.$, $P=0.0005$, adj. $\left.r^{2}=0.45\right)$ but not the Agriculture group $(P=0.08)$. Post-winter both groups were correlated with temperature averaged over the previous 7 days $\left(F_{1,19}=14.85, P=0.0011\right.$, adj. $r^{2}=0.41$ for the Agriculture group and $F_{1,19}=41.51$, $P<0.0001$, adj. $r^{2}=0.67$ ), and the regression slopes were similar (24.8 vs. 24.0) (Figure 4).

With respect to the 2015 data, within-hive temperature averaged over the first 7 days after sensor installation was significantly correlated with $\log$ adult bee mass (Oct. 26-Nov. 1, 2015) for the Frolich2 group $\left(F_{1,25}=9.30, P=0.0054\right.$, adj. $\left.r^{2}=0.24\right)$, but not for either EastThil $(P=0.58)$ or WestThil $(P=0.50)$. Average winter temperature (Nov. 20, 2015-Jan. 31, 2016) was not correlated with log adult bee mass in any group. However, hive temperature averaged over 5 days prior to hive inspection (Jan. 31-Feb. 4) post winter was correlated with all groups (EastThil, $F_{1,12}=15.47$, $P=0.0020$, adj. $r^{2}=0.53$; WestThil, $F_{1,12}=14.35, P=0.0038$, adj. $r^{2}=0.54$; Frolich2,
$F_{1,12}=19.94, P=0.0001$, adj. $\left.r^{2}=0.42\right)$. Regression slopes were less consistent among these groups than those in the 2014 experiment.

\subsubsection{Brood surface area and temperature amplitudes}

Temperature amplitudes averaged per hive over the first week of the study in 2014 were regressed on log capped brood area for both treatment groups; the regression was not significant for either group (Figure 5). Temperature amplitude was significantly inversely proportional only for hives from the Legge site $\left(F_{1,10}=11.46, P=0.007\right.$, adj. $\left.r^{2}=0.49\right)$. Some hives were observed to have cells with uncapped larvae, which were not included in the brood measurements. Post winter, temperature amplitudes in the CRP group were inversely proportional to brood surface area $\left(F_{1,10}=45.19, P<0.0001\right.$, adj. $\left.r^{2}=0.80\right)$ but not in the Agriculture group. No relationship between temperature amplitude and capped brood were observed among any groups in the 2015-2016 data; however, inspections indicated the presence of dead brood and those data would have interfered with the brood/temperature amplitude relationship. 


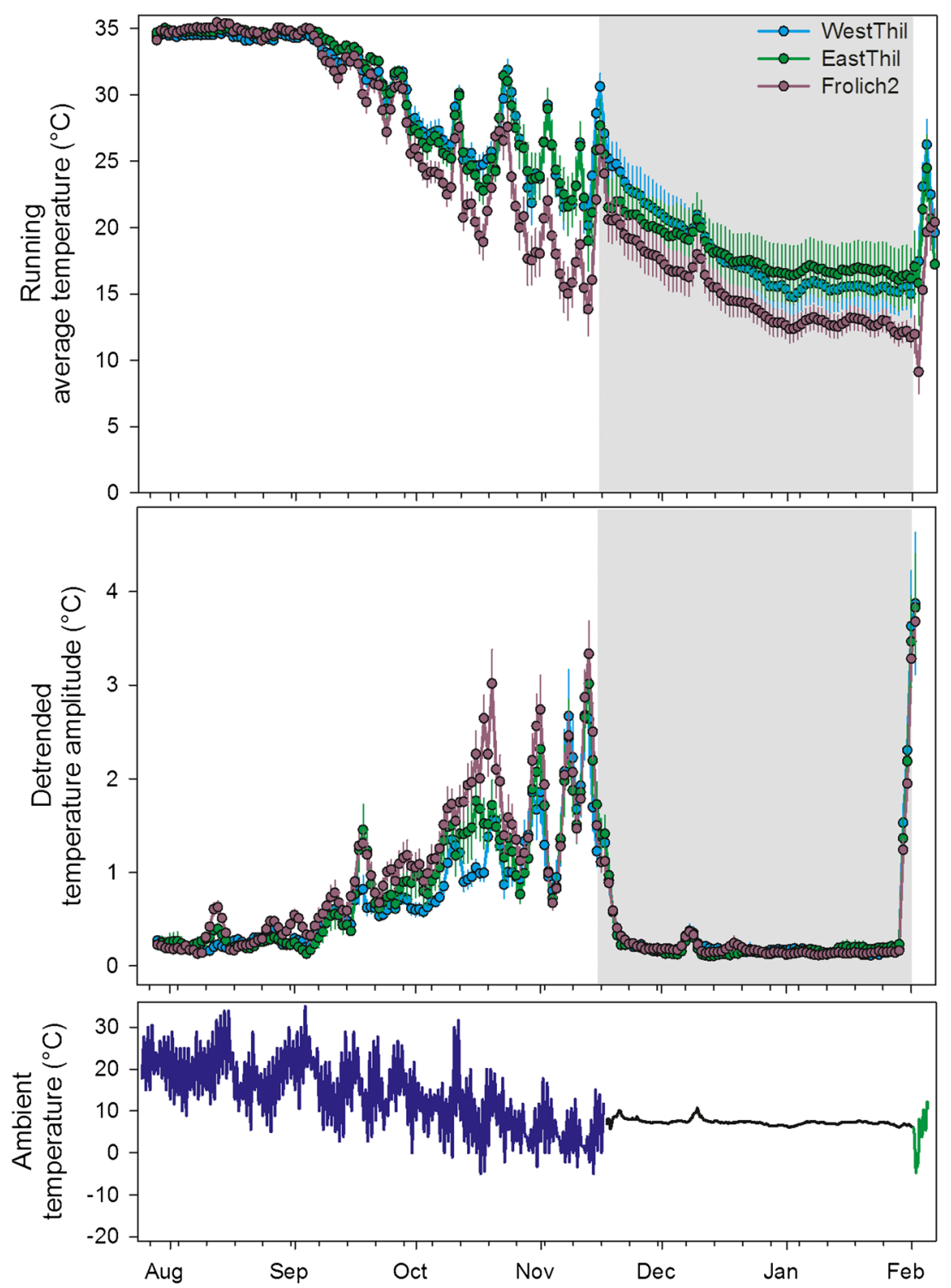

Figure 3. Average daily within-hive temperatures (a) and average daily detrended within-hive temperature amplitudes (b) for 64 hives in three treatment groups kept in ND, then installed in a warehouse near Firth, ID (indicated by the gray zone), and finally shipped near Snelling, CA; ambient temperatures during the study period (c), with blue line showing ambient temperatures in Valley City, ND (www.wunderground.com), black line showing ambient temperatures inside the warehouse in Idaho, and green line showing ambient temperatures during and after shipment to CA.

\subsection{Temperature and treatment group}

During the fall monitoring period, from Oct. 11 to Nov. 20, 2014, average temperatures were higher and detrended temperature amplitudes were lower in the CRP group than in the Agriculture group after controlling for adult bee mass (see Online Resource 3 Table S1). The same analysis for the winter dataset showed that hives in the CRP group had significantly higher temperatures 

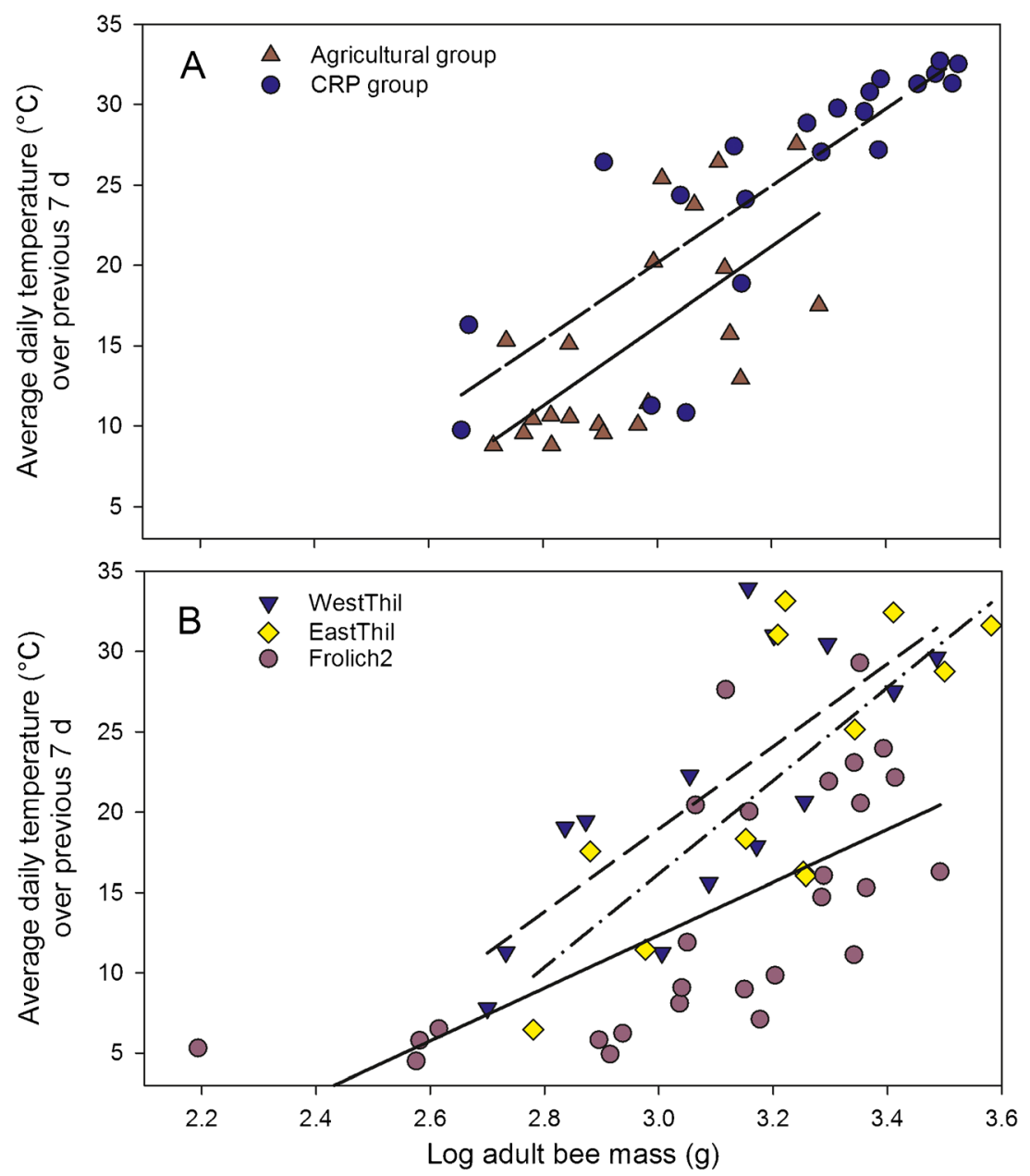

Figure 4. Average daily temperature as a function of adult bee mass post winter. a 2014-2015 experiment with two treatment groups. Solid line shows linear regression for the Agriculture group ( $N=21$ hives) and dashed line shows linear regression for CRP group $(N=21$ hives). b 2015-2016 experiment. Dashed line shows linear regression for the EastThil colonies $(N=16)$, dashed and dot line shows linear regression for the WestThil colonies $(N=16)$, and the solid line shows linear regression for the Frolich2 group ( $N=28$ hives).

than those in the Agriculture group. Two possibilities were considered: either colonies in the CRP group were generating more heat (or conserving heat better) per gram of bees, or bees in those groups were consistently closer to the temperature sensor. One test of that would be to compare upper and lower sensors during winter; if elevated upper sensor temperatures were simply due to a higher position of the bee cluster, then there should be a corresponding reduction in lower sensor temperatures. Considering the average temperatures while in storage (Nov. 25, 2014-Jan. 19, 2015), temperatures were significantly higher in the CRP colonies in both the upper sensor $\left(F_{1,27}=15.82, P=0.0005\right)$ and the lower sensor $\left(F_{1,27}=20.24, P=0.0001\right)$. Linear regression of average temperature after overwintering (Jan. 2027 ) on corresponding log total adult bee mass was significant for both the upper sensor $\left(F_{1,27}=72.46, P<0.0001\right)$ and the lower sensor $\left(F_{1,27}=57.94, P<0.0001\right)$ but the slope of the upper sensor $(29.0$, s.e. $=3.4)$ was greater than that for the lower sensor $(11.7$, s.e. $=1.5)$ (Figure 6; see also Online Resource 3 


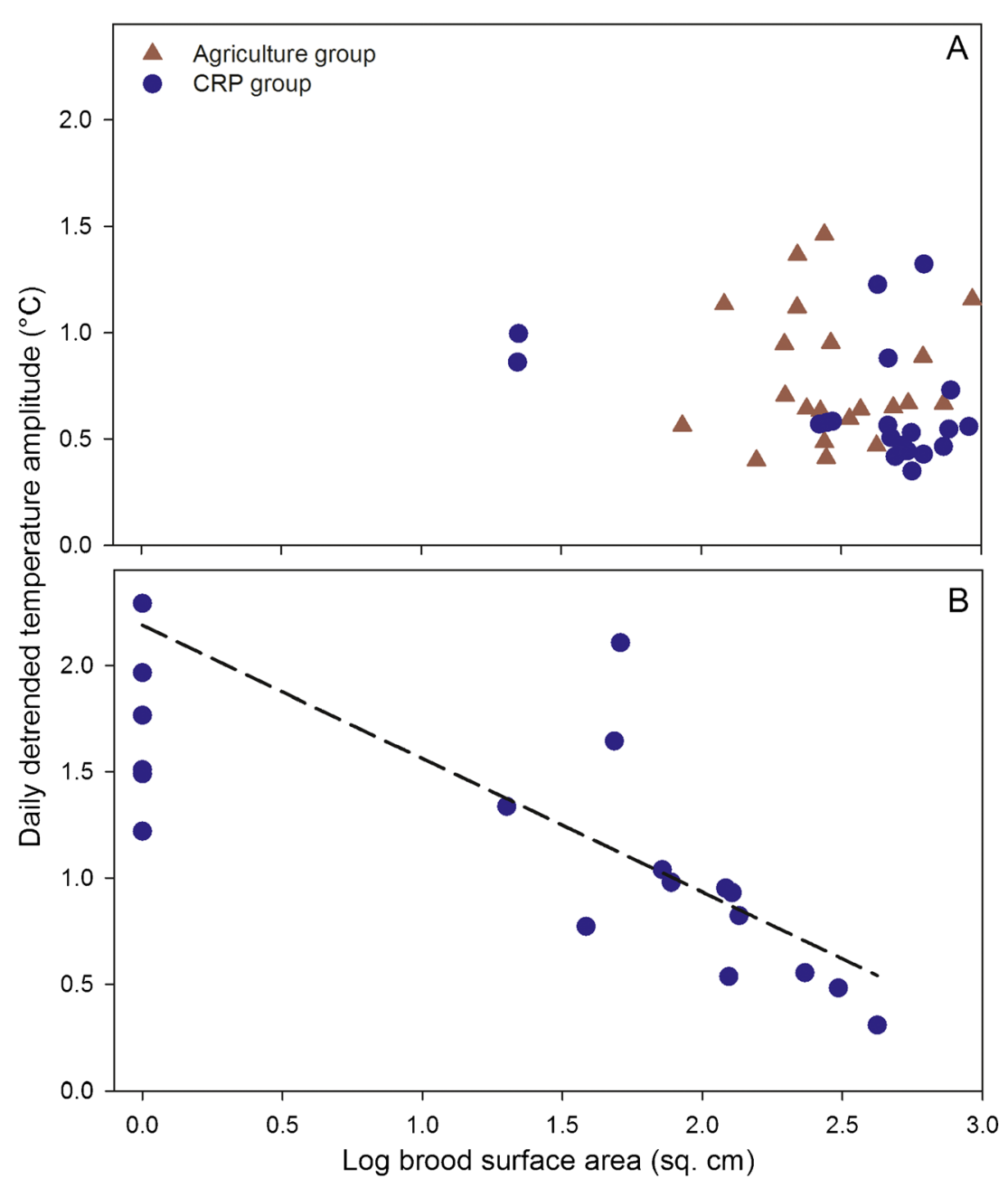

Figure 5. Log brood surface area $\left(\mathrm{cm}^{2}\right)$ as a function of daily detrended temperature amplitude averaged over the week prior to inspection for bee colonies in two treatment groups. a Data for both treatments in October 2014. b Data for all treatments post winter in January 2015. Dashed line shows linear regression for the CRP group (regressions for the Agriculture group was not significant).

Figure S2), suggesting that the temperature differences were not due solely to cluster location.

In fall 2015, treatment groups were significantly different with respect to average temperature but not temperature amplitude (See Online Resource 3 Table S2). Average temperatures in the WestThil group were higher than those in the Frolich2 group $(P=0.0092)$. No differences were observed among treatment groups with respect to average temperature during winter. Hives were removed from the warehouse on Feb. 1 and inspected on Feb. 5-6; average temperatures were significantly lower post winter in the Frolich2 group then either
EastThil or WestThil $(P=0.0158$ and $<0.0001$, respectively).

The Frolich1 and Frolich2 groups consisted of hives on the same migratory trajectory in successive years so comparing them might provide insight into yearly variability. No differences between groups were observed in terms of adult bee mass or frame weights, but colonies in Frolich1 had more brood in the fall $\left(F_{1,35}=29.86\right.$, $P<0.0001)$, with an average of $385 \pm 37 \mathrm{~cm}^{2}$ of brood, than Frolich2, with an average of $57 \pm 21 \mathrm{~cm}^{2}$. Hives in Frolich1 were warmer with lower temperature variability than those in Frolich2 


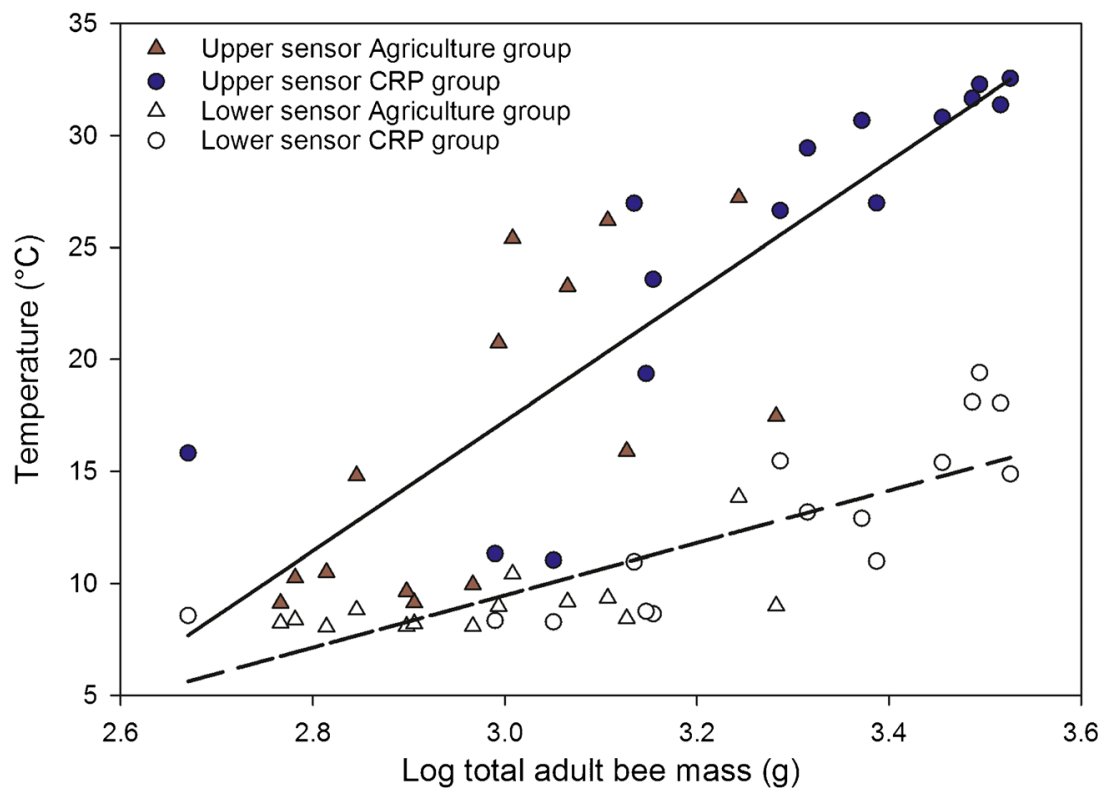

Figure 6. Average temperatures in 2015 for upper and lower sensors with respect to total adult bee mass for bee colonies in two treatment groups $(N=27$ hives total). Solid line shows linear regression for upper sensor data, and dashed line shows regression for lower sensor data.

in the fall, which would be consistent with more brood rearing (See Online Resource 3 Table S3).

\subsection{Varroa and Nosema densities}

Varroa and Nosema levels were evaluated with respect to treatment, sampling period (before and after overwintering), and their interaction. No significant differences were observed among treatments or between sampling periods with respect to Varroa, and no hives had high levels of mites (Table VI). Both N. ceranae and $N$. apis were observed but were not distinguished for statistical analysis. Nosema densities were significantly higher in colonies in the Agriculture treatment than the CRP treatment $\left(F_{1,82}=6.95, P=0.0100\right)$ and higher in spring than the fall $\left(F_{1,82}=15.85, P=0.0001\right)$. In the 2015-2016 season, the treatment group was not significant $(P=0.44)$ and Nosema densities were higher in the fall than in spring $\left(F_{1,52}=21.68, P<0.0001\right)$.

Table VI. Counts of Varroa and Nosema before and after overwintering for honey bee colonies kept in different landscapes in North Dakota

\begin{tabular}{|c|c|c|c|c|c|c|}
\hline \multirow[t]{2}{*}{ Year } & \multirow[t]{2}{*}{ Treatment group } & \multirow[t]{2}{*}{ No. of colonies } & \multicolumn{2}{|c|}{$\begin{array}{l}\text { Varroa: avg. no. mites per } 100 \\
\text { bees } \pm \mathrm{SE}\end{array}$} & \multicolumn{2}{|c|}{$\begin{array}{l}\text { Nosema: avg. no. spores per } \\
\text { bee }^{a} \pm \text { SE }\end{array}$} \\
\hline & & & Before & After & Before & After \\
\hline \multirow[t]{2}{*}{ 2014-2015 } & Agric. & 24 & $0.13 \pm 0.08$ & $0.30 \pm 0.18$ & $1.71 \pm 0.38$ & $4.67 \pm 0.89$ \\
\hline & CRP & 24 & $0.12 \pm 0.07$ & $0.40 \pm 0.24$ & $0.72 \pm 0.22$ & $3.16 \pm 0.92$ \\
\hline \multirow[t]{3}{*}{ 2015-2016 } & WestThil & 5 & $0.06 \pm 0.06$ & $0.29 \pm 0.20$ & $2.81 \pm 0.15$ & $0.24 \pm 0.12$ \\
\hline & EastThil & 10 & $0.28 \pm 0.25$ & $0.41 \pm 0.28$ & $2.68 \pm 0.25$ & $1.48 \pm 0.47$ \\
\hline & Frolich2 & 14 & $0.76 \pm 0.33$ & 0 & $2.72 \pm 0.17$ & $1.46 \pm 0.49$ \\
\hline
\end{tabular}

${ }^{\text {a }}$ Values $\times 10^{6}$ 


\subsection{Pesticide residues}

Agrochemical residue analyses of the bee bread collected in 2014 showed pesticides associated with Varroa control, including 2,4-dimethylphenyl- $N{ }^{\prime}$ methylformamidine (2,4-DMPF), a breakdown product of amitraz, coumaphos, fluvalinate, and thymol (See Online Resource 3 Table S4). Chlorpyrifos was found at all sites at concentrations from 4 to $35 \mathrm{ppb}$ in 2014 and from 18 to $144 \mathrm{ppb}$ (at the Frolich2 site) in 2015. The higher chlorpyrifos concentration may have played a role in the comparatively lower health indicators (brood production, temperature management) for the Frolich2 colonies compared to the Frolich1 colonies. The number of compounds detected was not higher in the Agriculture group in 2014 (8 in AG1 and 5 in AG2) than in the CRP group ( 7 in Legge and 11 in Frolich1). Bee bread samples collected in 2015 had fewer compounds, but this may be at least partly due to the different sampling methods, which were likely less sensitive than those used the previous year. Thymol concentrations were higher in 2015 than those observed in the previous year.

Analyses of the wax collected in 2014 showed residues of all the compounds found in bee bread, except for fluvalinate, in addition to six additional fungicides and an herbicide (see Online Resource 3 Table S5). Not all compounds were found at all sites, but the number of compounds per site varied little, from 11 (Legge) to 14 (AG2).

\section{DISCUSSION}

This study had two main goals: (1) evaluate hive temperature during overwintering to detect differences among bee hive groups subjected to different environments and (2) investigate group differences with respect to Nosema and Varroa densities and agrochemical residues. Temperature is controlled in a colony by the adult bee population (Kronenberg and Heller 1982; Stabentheiner et al. 2010) so the larger the bee mass, the greater the hive volume potentially under some degree of temperature control and thus the higher the expected average temperature, assuming that other factors, such as the ability and desire of the colony to maintain a high temperature, are equal. Internal hive temperature was found to be an effective response variable in detecting differences among colonies during winter and post winter, even before those effects manifested themselves on the colony level. In the first year, average temperatures differed among groups through winter storage until the end of January, after controlling for adult bee mass, indicating a treatment effect independent of colony size. Colonies in all groups lost adult bee mass during the winter storage; while hives in the CRP group in 2014-2015 lost about the same amount as those in the Agriculture group, they had started with a significantly larger bee mass and so were in better condition post overwintering. Hourly temperature was effective at distinguishing treatment groups before, during, and post winter in the 2014 experiment, but it was only strongly associated with adult bee mass post winter. In the 2015 experiment, hourly hive temperature distinguished groups outside of winter storage, but not during winter storage.

The relationship of temperature variability with the amount of capped brood was inconsistent in this study. Meikle et al. (2016b) found that stringent temperature control (= low amplitudes) in colonies with brood, but relaxed control (= high amplitudes) with little or no capped brood, was present. However, in the fall, 2014, experiment presented here, both capped brood levels and temperature amplitudes were significantly different between groups although they were not correlated with each other; only colonies from the Legge site had a significant relationship between capped brood and temperature amplitude at that time. Some uncapped brood was observed; uncapped brood levels were not measured and do not elicit as strong a temperature control response among bees as does capped brood (Stabentheiner et al. 2010), but it may have affected the temperature and capped brood analysis. If uncapped brood is not included in the brood measure, yet it affects temperature control by bees, then temperature variability may be lower than we expect for the observed levels of capped brood. Dead brood would have the opposite effect. Post winter, only one colony of 21 surviving colonies in the Agriculture group had capped brood while 13 of 22 colonies in the CRP group did, and amplitudes were correlated with the amount of brood in that group. That a positive relationship between brood levels and temperature amplitudes was observed in colonies from the strongest treatment group, and 
particularly among the strongest colonies within that group (from the Legge site), suggests that the lack of a relationship may indicate colony health issues, but further work is needed. In 2015-2016, relationships between capped brood and temperature amplitudes were either weak or not significant among all groups either before or after winter; the presence of dead brood noted in some hives would have interfered with that analysis.

What caused these differences between treatments in 2014 and among sites in 2015 was more difficult to determine. Varroa had been treated aggressively in the fall, and the low densities reflected that. Nosema densities were not different among groups but did change over winter, increasing the first year but decreasing the second. The impact of Nosema in this system needs further examination; fumagillin was applied, but it has been found ineffective in controlling $N$. ceranae (Huang et al. 2013). The incidence of viral diseases was not investigated, so that it possibility cannot be eliminated.

At least some evidence indicates that agrochemical exposure may have affected colonies. Chlorpyrifos was detected in many samples of stored pollen in this study and has been found to have strong synergistic effects with certain "bee safe" fungicides and beekeeper-applied miticides (Zhu et al. 2014). Data from the Frolich site in successive years showed that comparatively high levels of chlorpyrifos were detected in bee bread of colonies in the second year, as well as significantly less brood, lower average temperatures, and higher temperature variability compared to colonies in the first year. While that may be partly explained by the timing of the inspections, since hives in 2015 were inspected approximately 2 weeks later in the year than those in 2014, temperature data suggest that the brood production continued longer in 2014 than in 2015. No differences were observed during winter, or with respect to inspection data post winter, so the effect was short-lived. Smart et al. (2016) conducted a 3-year study with commercial hives in the same region and observed differential expression of nutritional and immune-related genes in worker bees from different locations (hives were not moved in that study) and a landscape effect on Nosema densities but no relationship between agrochemical residues and colony health. However, even slight differences in exposure may have comparatively large effects (Johnson et al. 2013; Johnson 2015).

\section{ACKNOWLEDGEMENTS}

Z. Browning, S. Cook, N. Holst, R. Oliver, and two anonymous reviewers greatly improved a previous version of this manuscript.

\section{CONTRIBUTIONS}

WGM and KEA conceived this research and designed experiments; all authors participated in experimental execution, WGM and KEA conducted data analysis and interpretation, and WGM, KEA, and MW wrote the paper.

\section{OPEN ACCESS}

This article is distributed under the terms of the Creative Commons Attribution 4.0 International License (http:// creativecommons.org/licenses/by/4.0/), which permits unrestricted use, distribution, and reproduction in any medium, provided you give appropriate credit to the original author(s) and the source, provide a link to the Creative Commons license, and indicate if changes were made.

La température interne de la ruche : moyen de vérifier la santé des colonies d'abeilles, avant et durant l'hiver, lors d'une opération de transhumance apicole

température de la ruche /poids des abeilles adultes production de couvain / résidu de pesticides / Nosema / amplitude des températures / phénologie de la colonie

Die interne Stocktemperatur als ein Parameter zur Überprüfung der Gesundheit von Bienenvölkern in einer Wanderimkerei vor und nach dem Winter

Stocktemperatur / Adultes Bienengewicht Brutproduktion / Pestizidrückstände / Nosema / Temperaturamplituden / Bienenvolk-Phänologie

\section{REFERENCES}

Chauzat M-P, Martel A.-C., Zeggane S., Drajnudel P., Schurr F., Clément M.-C., Ribière-Chabert M., Aubert M., Faucon J.-P. (2010) A case control study and a survey on mortalities of honey bee colonies (Apis mellifera ) in France during the winter of 2005-6. J. Apic. Res. 49,40-51. 
Dainat B., Evans J.D., Chen Y.P., Gauthier L., Neumann P. (2012) Dead or alive: Deformed wing virus and Varroa destructor reduce the life span of winter honeybees. Appl. Environ. Microbiol. 78,981-987.

Dively G.P., Embrey M.S., Kamel A., Hawthorne D.J., Pettis J.S. (2015) Assessment of chronic sublethal effects of imidacloprid on honey bee colony health. PLoS ONE 10:e0118748. doi: 10.1371/journal.pone.0118748.

Fries I., Chauzat, M.-P., Chen Y.-P., Doublet V., Genersch E., et al. (2013) Standard methods for Nosema research. J. Apic. Res. 52, 1-28.

Gates B.N. (1914) The temperature of the bee colony, United States Department of Agriculture, Dept. Bull. No. 96.

Genersch E., von der Ohe W., Kaatz H., Schroeder A., Otten C., et al. (2010) The German bee monitoring project: a long term study to understand periodically high winter losses of honey bee colonies. Apidologie 41, 332-352.

Harris J.L. (2009) Development of honey bee colonies on the Northern Great Plains of North America during confinement to winter quarters. J Apic. Res. 48,85-90.

Huang W.-F., Solter L.F., Yau P.M., Imai B.S. (2013) Nosema ceranae escapes fumagillin control in honey bees. PLoS Pathogens 9, e1003185.

Human H., Nicolson S.W., Dietemann V. (2006) Do honeybees, Apis mellifera scutellata, regulate humidity in their nest? Naturwissenschaften 93, 397-401.

Johnson R.M. (2015) Honey bee toxicology. Annu. Rev. Entomol. 60,415-434.

Johnson R.M., Dahlgren L., Siegfried B.D., Ellis M.D. (2013) Acaricide, fungicide and drug interactions in honey bees (Apis mellifera ). PLoS ONE. doi: 10.1371 /journal.pone.0054092

Jones J.C., Myerscough M.R., Graham S., Oldroyd B.P. (2004) Honey bee nest thermoregulation: Diversity promotes stability. Science 305, 402-404.

Kronenberg F., Heller H.C. (1982) Colonial thermoregulation in honey bees (Apis mellifera). J. Comp. Physiol. B 148,65-76.

Lee K.V., Moon R.D., Burkness E.C., Hutchison W.D., Spivak M. (2010) Practical sampling plans for Varroa destructor (Acari: Varroidae) in Apis mellifera (Hymenoptera: Apidae) colonies and apiaries. J. Econ. Entomol. 103, 1039-1050.

Lee K.V., Steinhauer N., Rennich K., Wilson M.E., Tarpy D.R., et al. (2015) A national survey of managed honey bee 2013-2014 annual colony losses in the USA. Apidologie, 1-14.

Meikle W.G., Holst N. (2015) Application of continuous monitoring of honey bee colonies. Apidologie 46,10-22.

Meikle W.G., Adamczyk J.J., Weiss M., Gregorc A., Johnson D.R., et al. (2016a) Sublethal effects of imidacloprid on honey bee colony growth and activity at three sites in the U.S. PLoS ONE 11(12): e0168603. doi:10.1371/journal.pone.0168603

Meikle W.G., Weiss M., Stillwell A.R. (2016b) Monitoring colony phenology using within-day variability in continuous weight and temperature of honey bee hives. Apidologie, doi:10.1007/s13592-015-0370-1.

Pettis J.S., Lichtenberg E.M., Andree M., Stitzinger J., Rose R., VanEngelsdorp D. (2013) Crop pollination exposes honey bees to pesticides which alters their susceptibility to the gut pathogen Nosema ceranae, PLoS ONE 8, e70182. doi: 10.1371/journal. pone. 0070182 .

Pickard R.S., El-Shemy A.A.M. (1989) Seasonal variation in the infection of honeybee colonies with Nosema apis Zander. J. Apic. Res. 28,93-100.

Runckel C., Flenniken M.L., Engel J.C., Ruby J.G., Ganem D., Andino R., DeRisi J.L. (2011) Temporal analysis of the honey bee microbiome reveals four novel viruses and seasonal prevalence of known viruses, Nosema, and Crithidia. PLoS One 6, e20656. doi: 10.1371 /journal.pone.0020656.

Schmolz E., Lamprecht I., Schricker B. (1995) A method for continuous direct calorimetric measurements of energy metabolism in intact hornet (Vespa crabro) and honeybee (Apis mellifera) colonies. Thermochimica Acta 251, 293-301.

Schwarz R.S., Bauchan G.R., Murphy C.A., Ravoet J., de Graaf D.C., Evans J.D. (2015) Characterization of two species of Trypanosomatidae from the honey bee Apis mellifera: Crithidia mellificae Langridge and McGhee, and Lotmaria passim n. gen., n. sp.. J. Eukaryot. Microbiol. 62(5),567-83 .

Simone-Finstrom, M., Li-Byarlay H., Huang M.H., Strand M.K., Rueppell O., Tarpy D.R. (2016) Migratory management and environmental conditions affect lifespan and oxidative stress in honey bees. Sci. Rep. 6, 32023; doi: 10.1038/srep32023 (2016).

Smart M.D., Pettis J., Rice N., Browning Z., Spivak M. (2016) Linking measures of colony and individual bee health to survival among apiaries exposed to varying agricultural land use. PLoS ONE 11(3), e0152685. doi:10.1371/journal.pone.0152685.

Stabentheiner A., Kovac H., Brodschneider R. (2010) Honeybee colony thermoregulation - regulatory mechanisms and contribution of individuals in dependence on age, location and thermal stress. PLoS ONE 5(1): e8967. doi:10.1371/journal.pone.0008967

Van Dooremalen C., Gerritsen L., Cornelissen B., van der Steen J.J.M., van Langevelde F., Blacquière T. (2012) Winter survival of individual honey bees and honey bee colonies depends on level of Varroa destructor infestation. PLoS ONE. doi: 10.1371/journal.pone.0036285

Wang Q., Xu X., Zhu X., Chen L., Zhou S., Huang Z.Y., Zhou B.F. (2016) Low-temperature stress during capped brood stage increases pupal mortality, misorientation and adult mortality in honey bees. PLoS ONE 11(5): e0154547. doi:10.1371/journal.pone.0154547

Zhu W., Schmehl D.R., Mullin C., Frazier J.L. (2014) Four common pesticides, their mixtures and a formulation solvent in the hive environment have high oral toxicity to honey bee larvae. PLoS ONE doi:10.1371/journal. pone. 0077547 . 